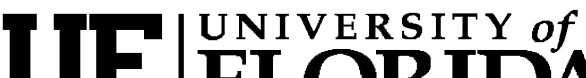 FLORIDA \\ IFAS Extension
}

FSHN0521

\section{Agroterrorism in the U.S.: An Overview ${ }^{1}$}

\author{
R.M. Goodrich, K.R. Schneider, C.D. Webb and D.L. Archer ${ }^{2}$
}

Since the attacks of $9 / 11$, vulnerabilities of the nation's infrastructure have been analyzed and discussed. The United States (U.S.) has identified the protection of national systems and infrastructure, such as the transportation, communication, water supply, and agriculture networks, as priorities to defend against terrorism.

Terrorism is widely defined as the unlawful use of force, violence, or implied harm against persons and property to intimidate or coerce a government, the civilian population, or any element of it, to further political, religious, or ideological aims.

Agroterrorism is the deliberate introduction of detrimental agents, biological and otherwise, into the agricultural and food processing system with the intent of causing actual or perceived harm. The broad areas of agriculture that could provide targets in an agroterrorism event are farm animals and livestock, plant crops, and the food processing, distribution, and retailing system.

The term bioterrorism will be widely used in this discussion, and in fact is closely related to agroterrorism. Bioterrorism is defined as the use of biological agents in a deliberate, harmful attack, or terrorism using the weapons of biological warfare such as anthrax, smallpox, or other pathogens. Bioterrorism attacks can be directed not only at agricultural targets, but also at the general public and key domestic infrastructure systems and personnel. The anthrax incidents involving tainted mail that occurred shortly after the $9 / 11$ events can be classified as bioterrorism. In the discussion herein, biological agents can be considered the most probable weapon used to launch an agroterrorism event.

\section{Consequences of a U.S. Agroterrorism Event}

Agriculture and the food industry are important to the U.S. economy. The USDA's Agricultural Research Service (USDA-ARS) estimates one person in eight works in some part of the agriculture/food sector. Cattle and dairy farmers alone earn about $\$ 50$ billion a year in meat and milk sales. Domestically, about $10 \%$ of the U.S. Gross Domestic Product (GDP) is related to agriculture and food production.

Even without agroterrorism, livestock disease costs the U.S. economy about $\$ 17.5$ billion and crop

1. This document is FSHN05-21, one of the Food Safety and Biosecurity White Paper Series, Food Science and Human Nutrition Department, Florida Cooperative Extension Service, Institute of Food and Agricultural Sciences, University of Florida. Published October 2005. Visit the EDIS Web site at http://edis.ifas.ufl.edu.

2. R.M. Goodrich, associate professor, Citrus REC, Lake Alfred, FL; K.R. Schneider, assistant professor, C.D. Webb, student, and D.L. Archer, professor, Food Science and Human Nutrition Department, Gainesville, FL; Cooperative Extension Service, Institute of Food and Agricultural Sciences, University of Florida, Gainesville 32611.

The Institute of Food and Agricultural Sciences (IFAS) is an Equal Opportunity Institution authorized to provide research, educational information and other services only to individuals and institutions that function with non-discrimination with respect to race, creed, color, religion, age, disability, sex, sexual orientation, marital status, national origin, political opinions or affiliations. U.S. Department of Agriculture, Cooperative Extension Service, University of Florida, IFAS, Florida A. \& M. University Cooperative Extension Program, and Boards of County Commissioners Cooperating. Larry Arrington, Dean 
diseases account for about $\$ 30$ billion. These are the baseline losses to which the financial impact of an actual agroterrorism event would be added.

In the event of an agroterrorism event that occurred in the U.S., the potential for disruption of our export market would be immense. International trade is crucial, as it provides a market for a major part of our crop production, and a growing share of meat output. Overall, $8 \%$ of the U.S. GDP was due to international trade. For comparison, about $30 \%$ of U.S. farm cash receipts were generated by exports. Proportionately, the U.S. agriculture industries rely on export markets more heavily than other sectors of U.S. industry. An agroterrorism event that instigated fear or even uncertainty in our international customers could be financially devastating to U.S. agricultural interests.

\section{Vulnerability of the U.S. Agriculture System}

Various factors lead to the heightened state of vulnerability of the U.S. to an agroterrorism event. As previously discussed, agriculture, food processing and food retailing contribute significantly to the U.S. economy, despite the perception of the ceaseless encroachment of urban growth into rural areas. As urban growth has occurred, agricultural operations, including farms, packinghouses, and processing plants have become larger, more centralized, and more intensive. It is this type of industrial concentration that perhaps increases the vulnerability of the U.S. agriculture system; as almost all agricultural sectors consolidate, their overall size generally increases. Thus, the impact of a targeted agroterrorism event affecting just one entity could still have a serious, adverse impact. For example, foot-and-mouth disease (FMD) confined to a very small geographically distinct herd is a vastly different situation than FMD occurring through intentional spread of the disease in a large cattle operation. Although large operations typically have greater economies-of-scale, they also lead to these types of vulnerabilities.

There are other reasons to be aware of the need to better security in agricultural operations. It is difficult and expensive to secure large areas of farm land with fences, gates and monitoring devices. Yet, it is incumbent upon producers to provide security in these areas. Packinghouses and processing plants are more easily controlled from a physical perimeter standpoint, but conversely have more personnel that need to be screened and then trained in specifics of plant security. More and more auditors focus on specific areas where their clients can improve their procedures and practices. Defense against terrorism must become ingrained in the normal operations of all agricultural operations before the U.S. can expect an improvement in the current state of readiness against an attack.

\section{The Bioterrorism Act of 2002}

The events of 9/11 reinforced the need to enhance the security of the United States. One broad area of vulnerability, as discussed, is the area of agriculture and specifically food production. The term food security, which traditionally meant the stability and supply of sufficient food for a given population, suddenly took on a different meaning. On June 12, 2002, the Public Health Security and Bioterrorism Preparedness and Response Act of 2002 (the Act) was signed into law by the U.S. Congress. The FDA is responsible for developing and implementing regulations on the following major provisions of the Act: Registration of Food Facilities, Prior Notice of Imported Food, Establishment and Maintenance of Records, and Administrative Detention. The definition of food used in these regulations includes food and beverages for human and animal consumption, including dietary supplements, infant formula, and food additives. It does not, however, cover food products such as meat and poultry that are regulated by the USDA-FSIS. The Act was designed to improve the ability of the U.S. to prevent, prepare for, and respond to bioterrorism and other public health emergencies.

\section{Prevention, Detection, and Mitigation}

Ideally, terrorism aimed at the food supply would be $100 \%$ preventable. In the aftermath of $9 / 11$, many resources were shifted from food safety to food biosecurity, with the intent to try to install sufficient deterrents that would lead to an improved condition 
of readiness within the agriculture and food sector.

State and federal agencies, along with trade organizations and third-party auditors, developed better and more thorough auditing tools and checklists that focused on security aspects for processing plants, their products and their personnel.

However, experience with naturally occurring outbreaks of foodborne disease has demonstrated that no existing preventive system is $100 \%$ effective. To some degree, improved speed of detection of a bioterrorism event can help mimize impact of a particular event. After 9/11, agencies increased their inspection and analytical capabilities in response to increased needs to respond quickly to a bioterrorism threat. The anthrax incidents that occurred after 9/11, although not specifically agroterrorism, highlighted to the authorities the need for a networked system of laboratories with pathogen and toxin detection capabilities.

Mitigation is one means of dealing with an actual or threatened agroterrorism event. The FDA, through the Bioterrorism Act of 2002, is requiring all food plants to register with the agency. They are also requiring prior notice for imported food shipments, as well as better record-keeping on the part of food processors and handlers. Should prevention fail, public safety falls to mitigation and containment strategies. One of the reasons the FDA is requesting this information is to enhance traceability of food products and the efficacy of product recalls. Recalls involve removing product from the commerce stream after they have left the distributor. Product may be in-transit, at the retail level, or even in the individual consumer's home. Retrieving the potentially contaminated product before it can be consumed is an effective way to limit the public health impact of contaminated food. Most biosecurity audits within food processing, handling, and retailing facilities now identify product recalls, and the ability to quickly and effectively execute them, as an important approach to their overall anti-terrorism strategy.

\section{Summary}

The U.S. has not been the victim of a large-scale, successful agroterrorism attack. However, there are serious vulnerabilities within our agricultural and food processing systems that must be addressed. Through an iterative process of risk assessment, risk control, and verification of implemented deterrents, all pertinent agricultural interests, regulators, scientists, and public health officials can improve the defensive position of this key industry and strive to reduce the threat of agroterrorism as much as possible.

\section{References}

Archer, D.L. and Degnan, F.H. 2002. Impact of the Bioterrorism Threat on the Food Industries. [Online] EDIS Florida Cooperative Extension Services publication FSHN02-08. Accessed 11 June 2005 at http://edis.ifas.ufl.edu/FS091

Benson, G.A., Marchant, M. and Rosson, P. 1998. U.S. Agriculture and International Trade. Texas Agricultural Extension Service Publication RM6-4.0. Accessed 22 June 2005 at http://trmep.tamu.edu/cg/factsheets/rm6-4.pdf

Levy, B.S. and Sidel, V., Eds. 2003. _Terrorism and Public Health - A Balanced Approach to Strengthening Systems and Protecting People. Oxford University Press, Inc., New York.

National Defense Research Institute. 2003. Agroterrorism: What is the Threat and What can be done about it? RAND Corporation website.

Accessed 11 June 2005 at http://www.rand.org/publications/RB/RB7565/

Rasco, B.A. and Bledsoe, G.E. 2005. Bioterrorism and Food Safety. CRC Press, Boca Raton. 